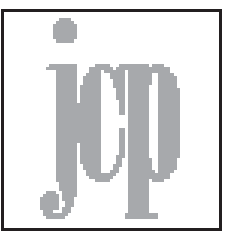

\title{
Modernity and Interpellated Native Subjectivity in South Asia
}

\section{Saeed Ur Rehman}

Department of English | University of Lahore

saeed@saeedurrehman.com

\begin{abstract}
Modernity is considered to be a normative social force that arrived in the Subcontinent with colonialism. Modern social organisation challenged indigenous loyalties and claims: the clan, the tribe, the village, caste relations, and the princely state. Normally, modernity is considered a unique attempt to transcend these loyalties. But celebration of modernity is an effect of colonial triumphalism and the Eurocentric desire to abnegate other such attempts in world cultures. Monotheistic social organisations were earlier attempts to transcend the family and the tribe and create a public sphere of faithful subjects. Modernity appears to succeed because of the support it received from the capitalist mode of production. For the native of the Subcontinent, such globalising attempts are not organic developments and need to be negotiated and contained. Literature and law helped the coloniser in maintaining the illusion that modernity was bringing a new and benign social order but the colony was just a site of surplus extraction.
\end{abstract}

Keywords: Modernity, South Asia, cultural transformation, literature, rationality 
This article is an attempt to problematise the idea of modernity in South Asia within the colonial context. In theoretical writing, the term 'modernity' is generally used in a Eurocentric sense: "When we speak of modernity... we refer to institutional transformations that have originated in the West" (Giddens 174). As to the question of whether modernity is a Western project, Anthony Giddens responds that "the blunt answer must be "yes"” (175). Even those theorists who are generally critical of the West take it for granted that the West has experienced modernity or that the contemporary West is a modern civilisation. To think in this manner, first a linear view of history has to be constructed and believed in, and then a sense of a lack, a lag or belatedness has to be constructed and applied to non-Western societies and civilisations. The West is imagined to have advanced to a historical stage that non-Western civilisations are trying to reach but, as Shashi Tharoor argues in his book An Era of Darkness:The British Empire in India, South Asia generally and India specifically was "no primitive or barren land, but the glittering jewel of the medieval world" (3). After extracting value and surplus through imperialistic economic policies and impoverishing the global south, the West acquired the material resources to celebrate the Eurocentric idea of modernity. The triumphalist narrative of the West being 'advanced' or 'civilised' was a discursive strategy to conceal the extraction of wealth from the colonies. Theorists from the Global South have tried to interrogate this idea of 'lagging behind' because it suggests "the belatedness of the black man", "postcolonial belatedness" and "the signifying time-lag of cultural difference” (Bhabha 236-238).

My argument in this article is that this linear periodisation produces a cultural condition that postcolonial theorists have to simultaneously engage with and problematise in order to privilege their own cultural specificity and, while doing so, they have to engage with a construct that is ambiguous and does not refer to any specific signified. Even as a signifier for a period in history, it functions mostly as a heuristic construct. Even the idea of linear history which orders cultural time into premodern, modern and postmodern stages is flawed because it is based on a selective analysis of cultural conditions. Moreover, once a culture or a society is called premodern, there is a supposition that it is trying to reach modernity.

The idea of temporal linearity and the word 'modernity' function as cognitive biases regardless of the fact that they are applied to the West or non-West. Once a culture, or part of a culture, is labelled 'premodern,' there is a normative force that comes into play: the premodern has to catch up with the modern. When this idea of modernity is combined with the colonising/ civilising mission, 
it helps the West to celebrate its present in relation to its past and simultaneously malign the present of non-Western civilisations which are imagined as having similarities with the past of the West. The idea of modernity helps the West treat its own past as the Other and its present as true to its own idea of a civilisational self. Therefore, one can posit that the birth of the idea of modernity in the West also marks the moment of the birth of the idea of primitiveness, which at once becomes applicable to the past of the West and the present of the non-West. Thus, an imagined present is produced in triumphant terms and an imagined past is produced in undesirable terms and, consequently, both are unleashed on a planetary scale. Social structures in non-Western societies that display similarities with the medieval or feudal social formations of Europe give rise to homologic thought and provide a justification for the colonising/civilising missions:

As European power expanded, this sense of the superiority of the present over the past became translated into a sense of superiority over those premodern societies and cultures that were 'locked' in the past — primitive and uncivilized peoples whose subjugation and 'introduction' into modernity became the right and obligation of European powers (Ashcroft et al. 161).

The word 'modern' and the condition of being modern (modernity), according to Habermas, is the expression of an era or epoch and its relation with the past. This relation enables the era or epoch to look at itself as "the result of a transition from the old to the new" (3). The tendency in Western thought which enables the West to view its past as having been superseded by a heroic present has been described by Michel Foucault as "the attitude of modernity" (38). This attitude of modernity is a paradoxical attitude because it views the past of Western and nonWestern societies as moving through stages of primitiveness, premodernity and modernity, displaying a linear continuity or progression and, at the same time, the past has a discontinuous relationship with the present. In contemporary social theory, the continuity hypothesis is exemplified by Habermas' contention that modernity is an incomplete but ongoing phenomenon (3). The rupture hypothesis is forcefully posited by Foucault in, among other writings, his essay "What is Enlightenment?" where he points out the contradictions and aporias in Immanuel Kant's celebration of the possibility of the "maturity" of human thought through the exercise of reason (306). As far as the West's civilisational interaction with other cultures is concerned, modernity has often been thought of in negative but paradoxical terms - a social condition that does not exist in non-Western societies but can be introduced, hence providing a justification for the civilising project which sought to realise itself through colonialism: "European imperial- 
ism is essentially the manifestation of European modernity spreading to wake up the world" (Pieterse xi). It is by defining its own modernity in relation to the 'primitiveness' of its own past Self as well as the present of its Other that the West justifies its civilising mission: "modernity was about conquest - the imperial regulation of land, the discipline of the soul, and the creation of truth" (Turner 4).

For many postcolonial intellectuals, a continuing and processual engagement with Western modernity is an unavoidable condition for producing any meaningful knowledge about and for their societies: "for so many of us of the third world, modernity came through as a powerful critique of our existing selves and systems, ergo as a higher and superior form of knowledge" (Radhakrishnan xix). Thus, it has become difficult, if not impossible, to discuss postcolonial social formations without discussing the effects and consequences of modernity which arrived riding high on the horses of British colonialism. In South Asia, the way modernity is imagined to be a rational process has often resulted in the entrenchment of what is called 'premodern' ways of thinking. This point can be illustrated by the example of a modern bureaucratic governmental technique, the census. According to John Brown, even an apparently insignificant governmental move such as the census taken by the British government, the technique of converting the colonised peoples into a manageable archive through enumerating and differentiating them on a communal and tribal basis, launched a new kind of politics; some theorists "attribute the birth of Hindu nationalism to the first British census, when people began to think of themselves as members of Hindu, Muslim, or Sikh populations" (5). Thus, 'modern' techniques of governmentality end up preserving the past of the Other and transforming the colonial project into a decivilising mission. If South Asia had not witnessed these forms of bureaucratic intervention, it might have produced its own culturally specific newness or an alternative modernity.

The newness introduced by the British often moved a pluralistic culture and polity into a more 'primitive' society whose bureaucratic archives produced majoritarian and minoritarian sentiments in communities. In contrast to this, the so-called premodern Mughal government displayed a more liberating relationship with its subjects. In 1670, a French doctor named François Bernier reported on the state of freedom existing in the Mughal empire:

In this same extent of country, there are sundry nations, which the Mogul is not full master of, most of them retaining yet their particular sovereigns and lords, that obey him not, nor pay him tribute but from constraint; many that do little, some that do nothing at all (135).

This shows that in some ways what is often interpreted as being premodern can 
also be interpreted as postmodern. Fragmented and shifting loyalties, the absence of a belligerent form of nationalism, and a vertiginous sense of disconnect with the state were the norm. Such cultural realities render the linear ordering of world history into premodern, modern and postmodern eras a problematic intellectual exercise. Therefore, a postcolonial theorist needs to liberate herself from this Eurocentric ordering of cultural conditions. The postcolonial theorist needs to produce a different way of imagining historical time instead of engaging with modernity and postmodernity and thus limit the global application of Western history as a normative model.

There was another crucial difference between Mughal rulers and British colonisers which must be highlighted: the Mughals were not using the colony as a source of raw material for a home country and they were also not expropriating resources from other continents to bolster their global empire. Their fates were linked with India. Their policies were not inspired by accumulating capital for a mother country:

What the English had in the early 1800s that the Marathas and the Mughals had not, was a form of government which had been unchanged since 1688, the accumulated sources of a century or so of triangular trade, and a lead in industrial production. It was a trading empire, nourished by the exploitation of two continents, with Africans labouring the Caribbean and American soil, which faced the Asian state formations (Pieterse 117-118; emphasis added).

During the British colonial period, South Asian society consisted of closed, autochthonous communities which rarely communicated with the world outside the village. As Fernand Braudel has noted, a typical village usually had everything it needed for the survival of its inhabitants, except salt and iron (238). Though Braudel describes the pre-modern village life, in terms borrowed from traditional economics, i.e. as a "subsistence economy," the picture that he portrays is more of an affluent and decentralised society: "close-knit, stable and self-sufficient communities, ruled by a chief or a council of elders, who in some regions even organized a redistribution of land" (238). The practice of describing premodern social formations as subsistence economies, as Pierre Clastres has theorised, actually conceals a different reality. The premodern economy is a subsistence economy not because of any incompetence but because of the absence of alienated labour: "once its needs are fully satisfied, nothing could induce primitive society to produce more, that is, to alienate its time by working for no good reason" (Clastres 197). Thus, another postmodern cultural reality is present in what is usually considered a premodern life - the absence of the work ethic introduced during the industrial era. 


\section{Muslim Response to Colonial Modernity}

Because the British government had replaced the Muslim rule, Muslim colonial subjects did not often subscribe to the idea that modernity, the official ideology of the colonial state, was a benign arrival on the social horizon. Colonised subjects were suspicious that the British had arrived to erase the cultural and religious identity of the colonised. According to Jan Pieterse, fear of the possible erasure of religious and cultural identity among the Muslim and Hindu sepoys was one of the causative factors of the 1857 Mutiny (Kiernan 205; Pieterse 121). The Mutiny, which was a "unique South Asian resistance movement comprising Hindus and Muslims" (Pieterse 124), was suppressed, and direct rule of the British Crown was imposed in 1858 when a Viceroy replaced the Governor General of the East India Company in Calcutta (Braudel 242). The British preserved and utilised the so-called premodern categories to support their modern bureaucratic governmental techniques. In 1772, Warren Hastings decreed:

[I]n all suits regarding inheritance, marriage, caste and other religious usages and institutions, the laws of the Koran with respect to the Mohammedans and those of the shaster with respect to the Gentoos (Hindus) shall be invariably adhered to; on all such occasions the Moulvies or Brahmins shall respectively attend to expound the law, and they shall sign the report and assist in passing the decree (Hastings qtd. in Rudolph and Rudolph 390).

When South Asian Muslim intellectuals observed a new alignment between premodern and modern categories of thought and government, they also started combining premodern and modern techniques. Maulana Ashraf Ali Thanawi sought to disseminate the ideas of the Sunni tradition of Islamic thought by employing modern techniques of book printing (D. Metcalf 19). In the early 1900s, Thanawi published Bahishti Zewar, which acquired ceremonial powers by becoming a compulsory component of dowry for a Muslim woman (D. Metcalf 3). Essentially a work concerned with the idea of maintaining the respectability of a Muslim woman, Bahishti Zewar attempted to construct a unified and wholesome sense of identity of a minority people under the colonial rule by providing guidelines for the management of domestic affairs (Jalal 72). This type of response was significant in the sense that it utilised what is considered modern technology (the printing press) to preserve what are generally considered premodern ideas of the ideal female subject who would manage the domestic sphere at a time when the Muslim male had already retreated from his dominant position in the public sphere. In this way, premodernity and modernity do not remain separate social realities and, in the present era in which a digitised PDF version of $\mathrm{Ba}$ hishti Zewar can be downloaded anywhere in the world, postmodern technologies 
disseminate premodern and modern masculine ideas of female respectability in cyberspace and, thus, all periodisations of historical time into neatly divided eras become futile.

Another way of interpreting the Bahishti Zewar phenomenon is that it was a clash of two modern sensibilities. If we want to interpret it in this way, we have to read monotheism as an early expression of a modernising sensibility. Monotheistic religions enjoin their followers to create a new type of imagined community which seeks to supplant familial and tribal solidarities. In monotheistic social formations, the belief in one God demands a new kind of solidarity and the erasure of familial, tribal and local deities. Monotheism was an early attempt to produce a social unity which is larger than the tribe and the village. Similarly, the modern nation-state seeks to make the ideas of territory and citizenship more important than all other premodern institutions that demand allegiances such as the family or the tribe. Because both require the subject to be independent of familial, local, or tribal loyalties, monotheism and modernity are compatible. Both operate on the logic of the Same and self-coherent rational systems which delegitimise local saints, local deities and culturally specific superstitions, and thereby claim universality. From this perspective, an all-knowing metaphysical entity and the surveillance of the nation-state have similar rational, calculative and punitive logics. Local sources of forgiveness and conviviality are othered by these universalising systems. In this way, modernity and monotheism have so many similarities that the argument that modernity is a Western historical stage becomes untenable.

To support the argument proffered above, I would like to offer an example from the discourse of a modern Muslim intellectual. In 1874, in an essay entitled "Musalmanon Ka Aflaas," or "The Poverty of the Muslims," Sayyid Ahmad Khan sketches out the conditions of Muslim subjects in colonial India in the following words: the "condition of Muslims is deteriorating rapidly. They are caught in a web of poverty and crime and the jails are full of them ... and they are losing their property in legal disputes" (qtd in Khan 163). After delineating the conditions of increasing indigence among Muslim subjects, Khan castigates them by citing articles published in contemporary newspapers which state that Muslims have lagged behind other communities over which they once ruled (164-165). The ideas of "lagging behind," "stagnation" and the desire to "catch up" with the West appear in the writing of Khan as dominant themes of his work for the rest of his life. In another article entitled "Mashraqi Aloom o Fanoon,"1 or "The Ori-

\footnotetext{
1. This article does not have its original publication date mentioned but it is included in the fifteenth volume (Khan 54-68) of Sayyid Ahmad Khan's Muqaalaat-e-Sir Sayyid. The title of the article and the quotations are translated by the author.
} 
ental Systems of Knowledge and Arts," Khan states that Lord Macaulay was a "pious and truthful statesman" who inaugurated a new phase in the development of knowledge in India (56) and the people of India should emulate the West as earnestly as possible:

If we Indians want real progress, it is incumbent upon us to forget our mother tongue. We should destroy all Oriental systems of knowledge [aloom-e-Mashraqi]. One of the great languages of Europe-either English or French - should become our language. And it is Europe whose systems of knowledge should be our main assets and tools [dast-e-maal]. Our brains should be brimful/overflowing [labraiz] with European thoughts (except in the matters of religion). It is we who have to learn how to dignify ourselves. We should always remain loyal to the British government and consider it as our great benefactor (66).

Khan finds the universalist logic of his metaphysics and Western modernity compatible because both systems have the same universalising spirit which seeks the erasure of vernacular languages, local saints and Sufis, and local customs. In this way, the intellect that designates this period as an era of modernity makes the mistake of considering equally universalising systems of thought as premodern. After the work of Gilles Deleuze, Felix Guattari and Pierre Clastres, we know that the logic of the state operates against the tribe by introducing an alienating form of political power. There is no difference between monotheistic rationality and modern rationality in the way they treat local, geographically limited epistemes.

In this way, the divide between monotheistic systems of thought and modern rationality becomes superfluous because both systems seek to interpellate culturally different non-universal subjectivities. Khan even found the theory of evolution compatible with his system of rationality. In an essay titled "The Creation and the Age of the Universe and Whether it Contradicts the Religion of Islam?," Khan accepted modern evolutionist theories of the creation of the universe by saying that "only Allah knows the real age of the universe" (1). Both systems of thought have their own internally consistent systems of rationality, which is challenged by culturally specific forms of knowledge.

Another superfluous division between premodernity and modernity is found in the line of argumentation which argues that modernity has changed the theocentric worldview into an anthropocentric one (Tarnas 272). The social order of modernity is often seen as having been brought about by the supposed dominance of rationality in the public sphere and the construction of the rational subject in the West. This claim has been declared a myth by Max Horkheimer and Theodor Adorno and in The Dialectic of Enlightenment, as well as by Deleuze and 
Guattari in Anti-Oedipus: Capitalism and Schizophrenia. Therefore, modernity may not be a useful term to describe any social reality in a stable and transparent manner. Contemporary postcolonial spaces are not marked by any singular tradition or even a binary of tradition and modernity. Contemporary South Asia displays countless cultural practices which can be simultaneously traditional and modern and have not yet been theorised adequately. In Pakistan, one can see sleek new Japanese cars with blank digital compact discs (CD's) hanging from the rearview mirrors. If one gets to examine these discs closely, one notices that they have $\mathrm{Du}$ aa-e-Safr printed on them. While their stereos blast out the latest gangster rap and qawwali fusions, these vehicles move along the roads without obeying any traffic signals when the police are not around. The postcolonial subject is not guided by either tradition, or by modernity, hybridity or postmodernity. This postcolonial space that is populated by the latest consumer products from Japan, America, and the United Kingdom, while blank compact discs hang with a printed Arabic script on them, is not a display of tradition, modernity or hybridity. In postcolonial South Asia, especially its urban segments, tradition, modernity and hybridity are at best convenient signifiers for the theorist because they enable the theorist to refer to some parts of the ensemble being examined. The whole ensemble is transforming so rapidly that any theorisation is challenged by counter examples that are offered by the prevailing cultural conditions.

Postcolonial subjects are not engaging in tradition, modernity, hybridity or postcolonial resistance. They are busy performing what Michel de Certeau has described as la perruque. La perruque, the French word for a wig, which consists of, in Certeau's theorisation, those strategies that the dominated employ within a given social order in order to subvert it "from within." La perruque does not seek to reject or transform the order of things but instead uses the established order to insert unprescribed or unauthorised practices. Through la perruque, "imposed knowledge and symbolisms become objects manipulated by practitioners [or users] who have not produced them" (Certeau 29-32). For the postcolonial subject, the established order is neither rational nor irrational because he or she has not been consulted or represented while it was being imposed. Therefore, the postcolonial subject does not engage in tradition, modernity or postmodernity but in a mode of survival, negotiations, performativity and simulations of all socially prescribed acts. All the sanctified cultural practices are performed as if a social script has to be acted upon and, whenever possible there is a chance, things are turned upside down or hollowed out and all the labels that can help to describe a cultural condition become empty signifiers. The cultural theorist, in his or her 
attempt to understand contemporary South Asia, is in a situation not very different from the legislator who is stunned by every new crime that has not been foreseen or defined in any penal code. The theorist has to invent a new vocabulary to explain contemporary cultural practices in South Asia and other sites where countless civilisational encounters have created shifting, uncategorisable historical realities all merging into one another at the same time.

Another manifestation of Western modernity in South Asia that is often ignored is the fact that many new techniques of governing large populations by interpellating their subjectivities through epistemes which are larger than the family, the tribe, or the village were first produced in the colonies and then repatriated to the colonising country. For example, the idea of free universal education developed in the colonies first and in England later. The East India Company, with its regulation in the hands of the British Parliament, was funding the education of natives in India before school children in England began receiving free education in 1918. In this instance, the colonising society tested many governmental techniques in the colonies first.

The colonists were divided on the issue of how to educate the natives of India between two camps: the Orientalists and the Anglicists. The Orientalists wanted to teach the South Asian subjects in their own languages and the Anglicists wanted to "lift up" the situation by imparting European knowledge to the natives. Warren Hastings had purchased the land for the establishment of a madrasa in Calcutta in 1780; and in 1791, Jonathan Duncan, an employee of the East India Company, proposed that a college for the promotion of Sanskrit grammar and Hindu philosophy be established in Benares (Sanskrit College, Benares). Both the maulvi and the pundit had been made happy by the British. Both of these institutions were receiving generous funds from the British.

The Orientalists who were working for the East India Company were quite content with this arrangement. The maulvi and the pundits were happy and, as the native religious elite, had formed a strategic alliance with the Company. The Anglicists felt that British support for promotion of the Oriental system of learning was not going to be helpful if they needed human capital to run the business of the empire for them. The Anglicists believed that theological debates and poetry were two areas in which Oriental knowledge excelled and it was not useful for the bureaucratic behemoth that the empire needed. In 1835, Thomas Babington Macaulay, in his famous "Minute on Indian Education," expressed this view in the following manner:

We must at present do our best to form a class who may be interpreters between us and the millions whom we govern, — a class of persons Indian 
in blood and colour, but English in tastes, in opinions, in morals and in intellect. To that class we may leave it to refine the vernacular dialects of the country, to enrich those dialects with terms of science borrowed from the Western nomenclature, and to render them by degrees fit vehicles for conveying knowledge to the great mass of the population (Macaulay qtd. in Young).

After Macaulay's demands, English became the medium of instruction through the promulgation of the English Education Act of 1835. Funds which were originally allocated for imparting the knowledge of Oriental languages and philosophy had to be reappropriated for promotion of the English language and European knowledge. After Macaulay's "Minute" and the English Education Act (1835), English was no longer the language of foreign rulers but a language of South Asia. Macaulay's impassioned views on the inferiority of Oriental systems of learning are now infamous: "a single shelf of a good European library was worth the whole native literature of India and Arabia. The intrinsic superiority of Western literature is indeed fully admitted" (Macaulay qtd in Desai 90). Colonial modernity was itself a schizophrenic enterprise because the colonisers who had taken up the 'civilising mission' had still not figured out how to implement modern techniques of producing governable multitudes.

The British colonialists in South Asia had captured the means of production and were extracting surpluses. They wanted to ensure the continuity of surplus extraction by producing predictable and docile subjects, and therefore sought to teach them English literature. Colonialism was not about modernising the natives but about making the natives governable in all the areas under the imperial rule. The divide between the missionary and the mercenary (the religious and the secular) colonisers was also an artificial divide, because neither side wanted the natives to rebel. They wanted the education system to ensure a continuous supply of helping hands. Luis Althusser articulated this function of ideology in his On the Reproduction of Capitalism: Ideology and Ideological State Apparatuses in the following words: "the ultimate condition for production is the reproduction of the conditions of production" (47). This insight lays bare the function of modern governments and we can see in the brief discussion on the colonisers' desire to teach English language and literature that, through their curricula of literary and philosophical studies, they wanted to reproduce the conditions of production within the minds of the natives. When the rebellion of 1857 erupted, both Orientalists and Anglicists blamed the education system of the other camp because their curricula had failed to produce those conditions in the minds of the natives which would ensure continuity of the production of surpluses. 
The people of South Asia have had their subjectivities interpellated (in Althusserian terms) and interrupted (in popular psychological terms) through formal education in which literature was an essential component. It means that those subjects who did not receive a formal modern education, who were not exposed to colonial syllabi, may have had greater chances of keeping their subjectivities intact. It means modern education itself was not a civilising instrument but a mask of conquest (Viswanathan).

The Orientalists and Anglicists did not try to create independent-thinking (un-interpellated) native subjects through their pedagogical inventions and interventions. Because the system of modern education was designed to create docile natives, we can argue that the educated elite were manufactured subjects who could help the empire perpetuate itself; and formal education, especially the study of English texts, inculcated a sensibility which alienated the native from his/her own culture. After having gone through this education, the native began to value literacy (especially the ability to read and interpret English texts) over orality, imported culture over local cultures, linear history over myth and superstition. Both Orientalists and Anglicists were against the 'uncivilised' native. The Brahman priest, the mullah and the English-medium-trained bureaucrat were the civilised natives. All the rest were supposed to come into the fold of this modernity-in-the-making and, if anyone displayed an anarchic sense of independence, they were declared habitual criminals. By the end of 1871, the Criminal Tribes Act was in place and entire tribes had been declared "habitually criminal," including their infants and children. All members of these tribes had to report their movements to the police. If any member of these tribes was found outside their designated geographical limits, he/she would be subjected to search and arrest. From Macaulay's Minute in 1835 to 1871 , the ideological thrust of imperial rule was clear: become modern or be declared an outsider, a criminal.

At the time of Independence of India and Pakistan, thirteen million people had been labelled as habitual criminals (Knafla 124). These 'uneducated' or 'uncivilised' people were looked down upon by "the educated and cultured" people of India because of their "unsettled bohemian ways" (124). The imperial order and the native elite were now 'on the same page' (a metaphor indicating an alliance of the literate) because both believed in the ideology of 'progress' and 'civilisation' "against the wanderers and vagrants who were outside the normal network of sedentary society” (R. Metcalf 122). Education, literacy and internalising the cultural capital of English language required a sedentary, propertied and working or bourgeois class lifestyle. Nomadic people (wandering tribal subjects) 
were thus "habitually criminal" because settling down and going to the same educational institution for years was not compatible with their way of life.

This alliance between the coloniser and the literate/educated native has continued even after the so-called independence. English continues to be the official language of the state and the law and a vehicle of whatever the modern episteme seeks to transmit. India, Pakistan and Bangladesh still have their penal codes based on the code drafted in 1835 by Thomas Babington Macaulay. The same person who campaigned for English to become the medium for educating the natives so that they could learn the modern vocabulary of science and administration was also the Chairman of the First Law Commission of India: "Macaulay's code was a most able piece of drafting...the work of a master of English prose, the code was concise, lucid, and free of legal jargon (Glazebrook 407). This document divided the people of South Asia into two broad categories. The law simultaneously created ideal subjects and condemned subjects. The law imagined subjects who were literate, productive and ready to follow the symbolic order of the empire as ideal subjects; whereas, those who were illiterate, vagrant, non-productive and recalcitrant were categorised as outsiders and a threat to the civilising or modernising mission.

This division between those who have 'understood' the orders of the emperor and those who remain 'uncivilised' still endures. Moreover, the law, as a written code, favours those who can read English because of the ancient legal dictum ignorantia juris non excusat (ignorance of the law does not excuse). A written legal code, when imposed on the entire population with this inherent assumption, ultimately favours the literate-especially those who can read the language in which the law is written. The rest of the population have to deal with the consequences of their own ignorance. This legal principle when applied to a society where the majority does not read, write or speak English betrays its twofold punitive heritage: the missionary and the imperial. The missionary heritage of this principle draws its power from the Old Testament: "If a person sins and does what is forbidden in any of the Lord's commands, even though he does not know it, he is guilty and will be held responsible" (Leviticus 17). While the modern imperial order seeks to punish those who do not receive the message by remaining 'ignorant' of English, the language of law and letters.

This intimate relationship between modern English law, English literacy, and colonialism was so powerful that it continues to shape the lives of millions of postcolonial subjects in India, Pakistan and Bangladesh. After the departure of the British, Pakistan remained a British dominion until 1956 and by that time Pa- 
kistan, through SEATO and CENTO, had entered into defence-related and structural relationships with the United States of America, another English-speaking global imperial power. Through its association with the United States, Pakistan continued to help the Western world order by following anti-Soviet and antiCommunist policies. The constitution and official business of the state remain in English. The postcolonial subject is still grappling with this legacy of colonial modernity. Western modernity has interrupted the local trajectories of history in South Asia and delayed the arrival of a dignifying present for the native. 


\section{Works Cited}

Althusser, Louis. et al. On the Reproduction of Capitalism: Ideology and Ideological State Apparatuses. Verso, 2014. Print.

Ashcroft, Bill. et al. Post-colonial Studies:The Key Concepts. 3rd ed. Routledge, 2013. Print.

Bernier, Francois. "Bernier's Voyage to the East Indies." A General Collection of the Best and Most Interesting Voyages and Travels in all Parts of the World. Ed. John Pinkerton. 8th vol. Longman, 1811. 57-234. Print.

Bhabha, Homi. The Location of Culture. Routledge, 1994. Print.

Braudel, Fernand. A History of Civilizations. Trans. Richard Mayne. Penguin, 1993. Print.

Brown, John R. "The Myth of Global Ethnic Conflict." Journal of Democracy 7.4 (1996): 3-14. Print.

Certeau, Michel de. The Practice of Everyday Life. Trans. Steven Rendall. UP of California, 1984. Print.

Clastres, Pierre. Society Against the State. Trans.Robert Hurley and Abe Stein. Zone Books, 1989. Print.

Deleuze, Gilles. et al. Anti-Oedipus: Capitalism and Schizophrenia. Penguin Books, 2009. Print.

Desai, Meghnad. The Rediscovery of India. Penguin Group, 2011. Print.

Foucault, Michel. "What is Enlightenment?" The Foucault Reader. Ed. Paul Rabinow. Pantheon Books, 1984. 32-50. Print.

Giddens, Anthony. The Consequences of Modernity. Stanford UP, 1990. Print.

Glazebrook, P. R. "Criminal Law Reform: England.” In Encyclopedia of Crime and Justice. 2nd ed. 1st vol. Macmillian, 2001. 400-412. Print.

Habermas, Jürgen. "Modernity_-An Incomplete Project.” Postmodern Culture. Ed.Hal Foster. Pluto Press, 1983. Print.

Horkheimer, Max and Theodor W. Adorno. Dialectic of Enlightenment. Trans. John Cumming. Verso, 1972. Print.

Jalal, Ayesha. Self and Sovereignty: Individual and Community in South Asian Islam since 1850. Sang-e-Meel Publications, 2001. Print.

Khan, Sayyid Ahmad. "Musalmano Ka Aflaas.” Muqaalaat-e-Sir Sayyid. 5th Vol. Ed. Maulana Muhammad Ismail Panipati. Majlas-e-Tarraqi-eAdab, 1962a. Print.

Khan, Sayyid Ahmad. "Dunya Kab Bani aur Kitni Muddat mein aur Mazhab Islam se iss ki Mutabaqat.” Muqaalaat-e-Sir Sayyid. 4th vol. Ed. 
Maulana Muhammad Ismail Panipati. Majlas-e-Tarraqi-e-Adab, 1962b. Print.

Khan, Sayyid Ahmad. "Mashraqi Aloom o Fanoon.” Muqaalaat-e-Sir Sayyid. 15th vol. Ed.Maulana Muhammad Ismail Panipati. Majlas-e-Tarraqi -e-Adab, 1963. Print.

Kiernan, V. G. Marxism and Imperialism. Edward Arnold, 1974. Print.

Knafla, Louis A. Crime, Gender, and Sexuality in Criminal Prosecutions. Greenwood Press, 2002. Print.

Metcalf, Barbara Daly. "Preface." PerfectingWomen: Maulana Ashraf Ali Thanawi's Bhishti Zewar. Translated by Barbara Daly Metcalf. UP of California, 1990. Print.

Metcalf, Thomas R. Ideologies of the Raj. 3rd Vol. Part 4, Cambridge UP, 1995. Print.

Pieterse, Jan P. Nederveen. Empire and Emancipation: Power and Liberation on a World Scale. Verso, 1989. Print.

Radhakrishnan, Rajagopalan. Diasporic Mediations: Between Home and Location. UP of Minnesota, 1996. Print.

Rudolph, Susanne Hoeber and Lloyd I Rudolph. "Living with Difference in India: Legal Pluralism and Legal Universalism in Historical Context." Religion and Personal Law in Secular India: A Call for Judgment, edited by Gerald James Larson, Indiana UP, 2001. Print.

Tarnas, Richard. The Passion of theWestern Mind: Understanding the Ideas that have Shaped our World View. Harmony Books, 1991. Print.

Tharoor, Shashi. An Era of Darkness: The British Empire in India. Aleph Book Company, 2016. Print.

Turner, Bryan S. "Periodization and Politics in the Postmodern." Theories of Modernity and Postmodernity. Edited by Bryan S. Turner, Sage, 1990. Print.

Viswanathan, Gauri. Masks of Conquest: Literary Study and British Rule in India. Columbia UP, 1989. Print.

Young, George M. Speeches by Lord Macaulay:With His Minute on Indian Education. Oxford UP, 1935. Print. 